\title{
The career diplomats: Sir Patrick Shaw, Alan Renouf and Sir Nicholas Parkinson, 1974-82
}

\section{David Lee}

In the years from 1974 to 1982, the Whitlam and Fraser governments followed the precedent established with the earlier appointments of Sir Keith Waller and Sir James Plimsoll of sending career diplomats to Washington. In contrast with the position from 1940 to 1964, when non-career diplomats had been appointed, Sir Patrick Shaw, Alan Renouf and Sir Nicholas Parkinson were all senior Foreign Affairs officers with extensive diplomatic experience. Shaw was a Deputy Secretary of the Department of Foreign Affairs, Renouf was Permanent Secretary of the department before being appointed to Washington, and Parkinson was appointed head of the department between his two terms as Ambassador to the United States. The three ambassadors, Shaw, Renouf and Parkinson, helped repair the Australia-US relationship after the period of significant tension, particularly in 1972 and 1973 when the Whitlam Labor Government was consistently at loggerheads with the Nixon Administration. Shaw's term straddled Labor and Coalition governments, while Parkinson and Renouf served a Coalition Government.

During the time after the US had ended its military commitment in Southeast Asia, the Fraser Government worried that Jimmy Carter's administration was not paying sufficient attention to the Asia-Pacific 
region and that the Australia, New Zealand, United States Security Treaty (ANZUS) was consequently decreasing in importance. The Fraser Government was also apprehensive that a possible US-Soviet disarmament agreement in the Indian Ocean might be to the detriment of the alliance.

Renouf and Parkinson, as heads of mission in Washington from 1976 to 1982 , maintained the strong tradition of previous ambassadors in Washington. They entreated the US to consult Australia and consistently emphasised the continuing importance of the ANZUS alliance and the significance of Australia as a partner in the Asia-Pacific region. The intensification of the Cold War in the late 1970s helped the envoys to achieve their objective. By the last year of the Carter Administration in 1980, the Soviet invasion of Afghanistan and developments in the Southeast Asian region had created a new geopolitical environment in which the ambassadors were able to help bring about intensified strategic cooperation between Australia and the US under ANZUS. Notwithstanding the revival of military cooperation under ANZUS, however, a wider problem loomed for Australian envoys in Washington of having to demonstrate Australia's importance to the American public as well as to the Executive and the Congress. Parkinson presciently identified a problem in 1982 that would be taken up by all his successors as head of mission in Washington.

\section{Sir Patrick Shaw}

Patrick Shaw was born on 18 September 1913 at Kew, Melbourne, the son of an Australian-born physician. He was educated at Ballarat and Scotch College and then the University of Melbourne. ${ }^{1}$ After joining the Commonwealth Public Service in 1936, he transferred in 1939 to the Department of External Affairs, Australia's fledgling foreign office. In 1940, Shaw was posted as Third Secretary to the Australian legation in Tokyo and, after the outbreak of the Pacific War, was interned along with other legation staff until exchanged for Japanese diplomats in August 1942. Shaw subsequently served at the Australian High Commission in New Zealand from 1943 to 1945, and again in Tokyo in the late 1940s. From 1956 to 1959 he was Australia's Ambassador to

1 David Lee, 'Shaw, Sir Patrick (1913-1975)', Australian Dictionary of Biography, vol. 16, 1940-1980, Melbourne University Press, Carlton, 2002, pp. 220-21. 
the Federal Republic of Germany and then Ambassador to Indonesia from 1960 to 1962. As Australian envoy in Jakarta he supported a policy, unpopular with the Menzies Government at the time, of acceding to Indonesia's wish to incorporate West New Guinea (Irian Jaya). ${ }^{2}$ Shaw was Deputy Secretary to Sir ArthurTange from 1964 to 1965 at the time when Australia began its military involvement with the US in South Vietnam. From 1965 to 1970 he was Australia's Permanent Representative to the United Nations, New York, and then High Commissioner in New Delhi from 17 April 1970. Shaw's apparent intention was to retire from the public service at the end of his diplomatic service in India.

His plans were altered by decisions of the Whitlam Labor Government. Sir James Plimsoll had commenced his appointment in Washington in 1970 at the same time as Shaw began his posting in New Delhi. Plimsoll had hopes of serving in Washington for as long a time as Keith Waller and Howard Beale before him. But, as Jeremy Hearder notes in the previous chapter, during Gough Whitlam's visit to Washington in 1973, Plimsoll received a personal letter from the Prime Minister advising him that, after three years in Washington, he would be transferred to Moscow.

As noted, Plimsoll's transfer to Moscow at Whitlam's behest was part of a series of appointments to key diplomatic posts. Sir Keith Waller, now the Permanent Secretary of the Department of Foreign Affairs, had been doing all he could to make Washington available for Shaw. Waller had attended the same school and university as Shaw and had formed a high regard for him. Indeed, Waller may have felt some sensitivity that he had risen to head the Department of Foreign Affairs while the exceptionally able Shaw had not managed to do so. ${ }^{3}$ On 26 September 1973, Whitlam announced the appointment of Shaw to Washington, Plimsoll to Moscow, Grant to New Delhi and another senior Department of Foreign Affairs official, Keith Shann, to Tokyo. ${ }^{4}$

Shaw presented his letters of credence to President Richard Nixon on 13 March 1974. In doing so, Shaw remarked:

2 Ibid

3 Jeremy Hearder,Jim Plim: Ambassador Extraordinary: A Biography for Sir James Plimsoll, Connor Court, Ballarat, 2015, p. 250.

4 Edward Gough Whitlam, 'Senior Diplomatic Appointments', Current Notes, vol. 44, September 1973, pp. 622-4. 
There is a fundamental continuity in Australian policies which is symbolised by ANZUS which remains Australia's most important and enduring treaty because it embodies permanent and natural elements in the relations between our countries. ${ }^{5}$

Shaw's term in Washington would be even shorter than Plimsoll's - from March 1974 until his untimely death in December 1975. In that period, however, he helped the Whitlam Government smooth the difficulties in the relationship that had surfaced in 1972 and 1973 when it had clashed repeatedly with the Nixon Administration. ${ }^{6}$ The first year of Shaw's posting, 1974, was also consumed by the Watergate crisis that ultimately led to Nixon's resignation and his replacement by Gerald R Ford, who succeeded to the presidency on 9 August 1974. Shaw was increasingly called upon not only to explain Australian policy and attitudes to the US Government and public but to help explain changes in the US to the Australian public. Shaw was no less active than Plimsoll in making speeches and giving addresses across the US. The US reaction to the Watergate crisis, and an 'imperial presidency' that had developed since World War II, affected the Australia-US relationship by making US foreign policy initiatives more difficult and US commitments more fragile, particularly in the Asian region. After Watergate, presidential power was circumscribed and Congressional scrutiny of administration programs increased. ${ }^{7}$

By February 1975, Shaw was able to report to the Minister for Foreign Affairs, Senator Don Willesee, that the Whitlam Government 'could properly claim to have successfully brought a new understanding into Australia's relationship with the United States of America'. Shaw remarked that the difficulties in the Australia-US relationship during 1973 were largely concerned with the divisive factor of the Vietnam War. But in Shaw's assessment, it was understandable that there would be differences of views between an Australian Labor Government in Canberra and a Republican Administration in Washington. He explained:

5 'Australian Ambassador to US Presents Letters of Credence', Australian Foreign Affairs Record, vol. 45, March 1974, p. 183.

6 See generally James Curran, Unholy Fury: Whitlam and Nixon at War, Melbourne University Press, Carlton, 2015.

7 'Call on His Excellency the Governor-General by Mr N.F. Parkinson, Australian Ambassadordesignate to the United States', 8 October 1979, series A1838, item 1500/2/27/12 part 1, National Archives of Australia (NAA), Canberra.

8 Shaw to Willesee, 14 February 1975, letter, series A1838, item 250/9/924 part 1, NAA, Canberra. 
One does not expect the views of the Australian Labor Government to coincide with those of the United States Republican Administration any more than one expects the views of the American Democrats in Congress to coincide with those of the [Republican] American Executive. ${ }^{9}$

Shaw noted to Renouf, the Secretary in Canberra, that the US State Department had prohibited any comment whatsoever on the Australian Labor Party Conference in Terrigal, New South Wales, in February 1975. At this meeting, the Australian Labor Party had passed a resolution calling for an Australian diplomatic relationship with the South Vietnamese Provisional Revolutionary Government (PRG). Shaw warned that Ford's administration would be concerned about the possible repercussions of Australia establishing relations with the PRG and recommended that the government weigh the future of Australia's relationship with the PRG against the damage to Australia's relations with the US. Shaw added:

The achievement of the last year was noteworthy in that two Governments of two different political complexions saw beyond differences which were less important and probably temporary. If we can possibly avoid it, we do not want these less important differences to become part of the internal political debate in either country to the detriment of our overall relationship. ${ }^{10}$

Despite Shaw's admonitions, the Whitlam Government recognised the PRG in South Vietnam on 6 May $1975 .{ }^{11}$ The Ford Administration, however, took the decision in its stride. Philip C Habib, a US Assistant Secretary of State visiting Australia at the end of May, noted that 'we seemed to have passed through the rough patches in bilateral relations' and that Whitlam's recent visit had been 'first class'. ${ }^{12}$

The visit to which Habib referred was Whitlam's third to the US; it took place in May 1975. During this visit, Whitlam had discussions with Vice President Nelson Rockefeller, Secretary of State Henry Kissinger and President Ford. ${ }^{13}$ In a major address to the National Press

9 Ibid.

10 Ibid.

11 'South Viet-Nam: Australian recognition', Australian Foreign Affairs Record, vol. 46, May 1975, p. 296.

12 Discussions in Canberra between Australian officials and Philip C Habib, 23 May 1975, series A1838, item 250/9/1 part 23, NAA, Canberra.

13 'Visit of Mr Whitlam to the United States', Australian Foreign Affairs Record, vol. 46, May 1975, p. 264. 
Club in Washington on 8 May 1975, Whitlam characterised the allied intervention in Indochina in the 1960s and 1970s as a tragic mistake foredoomed to failure, applauded the thrust of US policy in aiming for détente with the Soviet Union and announced that Australia 'had lent her voice to the maintenance of a zone of peace in the Indian Ocean. ${ }^{14}$ Throughout 1975, Shaw and the embassy staff in Washington were busy facilitating not only Whitlam's but also other ministerial visits. In 1975 Willesee visited the US twice - for a meeting of the ANZUS Council in Washington in April and then to attend the UN General Assembly in New York in September. Shaw joined Willesee in a small Australian delegation to the ANZUS Council meeting. Whitlam's Minister for Defence, Bill Morrison, also had discussions with the US Secretary of Defense James R Schlesinger in August.

In his role as Ambassador to the US, Shaw not only explained Australia to the US but he also helped the Australian public to understand its Pacific neighbour. For example, on a visit to Australia in September 1975, Shaw spoke on ABC radio about developments in the Australia-US relationship during his time in Washington. He noted that the change of government in Australia in 1972 had produced occasional harsh words, but that 'these have been put into perspective by the American leadership and both sides know they neither take one nor other for granted, but both accept the importance of the one to the other'. ${ }^{15}$ Shaw concluded his address with the words:

So if I have a message for you tonight, it is this, that Australia has a new sort of relationship with the United States, it's an independent one, it's one of mutual understanding and respect, but in ways which few of us have taken aboard, there is a new game being played in world diplomacy and in this Australia has a part to play, it's partly an independent line and also partly in co-operation with our main ally and friend, the United States of America. ${ }^{16}$

The convulsive political crisis of Watergate in the US in 1974 was paralleled by a constitutional crisis in Australia. On 11 November 1975 the Governor-General, Sir John Kerr, dismissed the Whitlam Government and installed the Leader of the Opposition, Malcom

14 Edward Gough Whitlam, 'Partnership in Peace', address to the National Press Club in Washington, DC, 8 May 1975, Australian Foreign Affairs Record, vol. 46, May 1975, p. 268.

15 Patrick Shaw, Radio Special Projects, 28 September 1975, series A1838, item 250/9/1 part 23, NAA, Canberra.

16 Ibid. 
Fraser, at the head of a caretaker government pending a double dissolution election in December 1975. During this caretaker period, Shaw warned that the Ford Administration 'will be hyper-sensitive about commenting on anything which might be interpreted as interfering in the domestic process in Australia'. ${ }^{17}$ He added that '[i]t will be a delicate and difficult time which I hope we can get through without damage to the Australian-American relationship'. ${ }^{18}$ The caretaker period ended without damage to Australian-American relations, although there was periodic media questioning of whether the US Central Intelligence Agency might have had a role in the premature end of the Whitlam Government. ${ }^{19} \mathrm{~A}$ coalition of the Liberal and National Country parties was elected in a landslide in the general election on 13 December 1975.

Fraser's electoral victory was met with relief in the US. Ford hailed the victory, conveying to Fraser his congratulations. Not long after the election, Shaw announced to a luncheon in New York on 17 December 1975:

Now we turn back more to our old friends amongst those old friends the most important is the United States of America. We have never been non-aligned because we have the Australian-United States-New Zealand alliance, which is our prime security pact, and we have always kept that in the foremost parts of our minds and will continue to do so. ${ }^{20}$

Shaw prepared himself for a busy time after the election in introducing the newly formed Fraser Government to the Ford Administration. But in tragic fulfilment of Keith Waller's premonition that three years in Washington was 'as long as flesh and blood could stand', ${ }^{21}$ Shaw suffered a heart attack. He died in Georgetown University Hospital on 27 December 1975. The strain of his two years in Washington had been exacerbated by an earlier assault on his wife outside the Residence.

17 Shaw to Andrew Peacock, Minister for Foreign Affairs, 12 November 1975, letter, series A1838, item 250/9/1 part 23, NAA, Canberra.

18 Ibid.

19 See Brian Toohey and William Pinwill, Oyster: The Story of the Australian Secret Intelligence Service, Heinemann, Port Melbourne, 1989.

20 Remarks by Sir Patrick Shaw to Australian Association Lunch, New York, 11 December1975, series A1838, item 250/9/1 part 23, NAA, Canberra.

21 Reminisciental Conversations between Hon. Clyde Cameron and Sit James Plimsoll, 1984, TRC 1967, vol. 11, p. 324, National Library of Australia (NLA), Canberra. 
Shaw's death was followed by messages of condolence from leading members of the administration. The Secretary of State, Henry Kissinger, for example, cabled the Australian Government: 'We are shocked and saddened at the untimely death in Washington this evening of Sir Patrick Shaw. He has been an outstanding Ambassador, as well as friend and confidante to us all.'22 Although Shaw's own political opinions were more in sympathy with the Coalition than with Labor, he was a loyal emissary of the Whitlam Government, accurately reporting from Washington and skilfully advocating government policy. The tributes that he earned on his death were testimony to the esteem in which he was held by members of the US Government and of Congress.

\section{Nicholas Parkinson (first term)}

The Fraser Government chose another seasoned diplomat, Nicholas Parkinson, to succeed Shaw as Ambassador to the US. Andrew Peacock, Fraser's Minister for Foreign Affairs, announced Parkinson's appointment on 1 February $1976 .{ }^{23}$ Nicholas Parkinson was born in Horsham, England, on 5 December 1925, the son of the English-born Reverend Charles Tasman Parkinson, who migrated to Australia to become principal of King's School Parramatta, bringing his son Nicholas with him. Nicholas was educated at King's School Parramatta and then at the University of Sydney, from which he graduated with a Bachelor of Arts degree. After serving in the Royal Australian Air Force between 1943 and 1946, he joined the Department of External Affairs as a cadet and then studied in the School of African and Oriental Studies at the University of London in 1952 and 1953. He was a junior diplomat in Cairo from 1953 to 1956, then a Second Secretary in Hong Kong from 1958 to 1961. Postings followed in Wellington from 1963 to 1965 and Kuala Lumpur from 1965 to 1967. Between 1967 and 1970 he served as the assistant secretary responsible for the Joint Intelligence Committee before serving as High Commissioner to Singapore from 1970 to 1974. Parkinson was one of two deputy secretaries in the Department of Foreign Affairs from 1974 to 1976.

22 Embassy in Washington to Department of Foreign Affairs, 29 December 1975, cablegram no. 30242, series A1838, item 250/9/1 part 23, NAA, Canberra.

23 'Appointment of Ambassador to the United States', Australian Foreign Affairs Record, vol. 47, 1976, pp. 95-6. 
Parkinson commenced his appointment in Washington on 6 March 1976 but spent less time in Washington than even Shaw, serving less than a year before returning to Canberra in order to succeed Alan Renouf as Permanent Secretary of the Department of Foreign Affairs. Parkinson presented his credentials to Ford on 16 March 1976. He commented to Canberra that the promptness of his presentation of credentials was an indication of the favour that the Fraser Government had found with the Ford Administration. He informed Canberra that the early presentation of credentials was 'intended as a deliberate gesture of friendship' and that 'the ceremony was specially arranged without other ambassadors in the queue'. ${ }^{24}$ When Parkinson began his term in Washington, Sir John Kerr's dismissal of the Whitlam Government had exacerbated anti-American feeling that originated in a campaign against the allied war in Vietnam but later included opposition to uranium mining and to the possibility that the ANZUS alliance and the joint defence facilities might lead to the nuclear targeting of Australian cities. This growth of anti-American sentiment was highlighted in September 1976 when the president of the Australian Council of Trade Unions and future Labor Prime Minister, Bob Hawke, signed an advertisement pledging opposition to military alliances, foreign military bases and military interventions. ${ }^{25}$ Hawke's signature was ironic in view of his subsequent strong support for the ANZUS alliance as Australian Prime Minister in the 1980s.

Notwithstanding the change from Whitlam to Fraser, some observers of the Australia-US relationship detected a longer-term change in Australia's attitude to the relationship in the 1970s that was independent of political allegiance. Writing in the New York Times on 21 December 1975, Australian journalist Harry Gordon wrote:

Australia's recent attitude towards the United States has veered from the sycophantic to the abusive. This ambivalence is not just a consequence of varying periods of power by two opposing political parties in Australia. It reflects a love-hate condition that diplomats and historians down the years have chosen to call a 'special relationship. ${ }^{26}$

The new Prime Minister, Malcolm Fraser, highlighted the change in the nature of the Australia-US relationship in the 1970s as compared with the relationship in the 1950s and 1960s when he told the House of

24 Parkinson to Department of Foreign Affairs, 16 March 1976, cablegram no. WH29577, series A1838, item 1500/2/27/10 part 1, NAA, Canberra.

25 'Hawke Calls for an End to ANZUS', Sun Nerws Pictorial, 18 September 1976.

26 Harry Gordon, 'Australia’s Foreign Policy Readjustments', Neww York Times, 21 December 1975. 
Representatives that 'the interests of the United States and the interests of Australia are not necessarily identical. In our relations with the United States, as in our relations with other great powers, our first responsibility is independently to assess our interests'. ${ }^{27} \mathrm{He}$ continued:

Of all the great powers with active interests and capabilities in the areas of critical concern to Australia, the United States is the power with which we have closest links... As long as Australia values freedom and respect for the individual, the United States is the power with which we can realistically establish close and warm friendship and with which we can most closely work to advance world peace and the humane values we share. ${ }^{28}$

Parkinson and the embassy in Washington facilitated a visit by Fraser to Washington in June 1976 after earlier trips he had made to Japan and China. The Ambassador was active in shaping the agenda of the discussions between Fraser and Ford, particularly on how the two leaders saw the Australia-US relationship being developed and what strategic insights Fraser had learned from his visit to China and Japan. ${ }^{29}$ During his visit to Washington, Fraser evoked not the 'All the Way with LBJ' rhetoric of Coalition predecessors like Harold Holt, but rather a mood of 'calculated and pragmatic national self-interest'. ${ }^{30}$ Fraser repeated what he had earlier told parliament in Canberra: that the interests of the US and the interests of Australia were not necessarily identical. ${ }^{31}$

One of Parkinson's great skills was in organising all aspects of Fraser's first visit as prime minister to the US. So successful was the embassy's management of the visit that Parkinson later sent the embassy's notes to the Department of the Prime Minister and Cabinet to be used as a template for future prime ministerial visits abroad. ${ }^{32}$ Fraser was personally impressed by Parkinson's handling of the visit, a factor that

27 Quoted in Glen Barclay, 'Australia and North America' in Peter John Boyce and Jim R Angel (eds), Independence and Alliance: Australia in World Affairs 1976-80, George Allen \& Unwin, North Sydney, 1983, pp. 146-7.

28 Ibid., p. 147.

29 Embassy in Washington to Department of Foreign Affairs, 9 July 1976, cablegram no. WH34793 series A1209, item 1976/1422 part 2, NAA, Canberra.

30 Barclay, 'Australia and North America', p. 146.

31 Ibid.

32 Parkinson to James Scholtens, Director, Office of Government, Ceremonial and Hospitality, Department of the Prime Minister and Cabinet, 10 August 1976, letter, series A1209, item 1976/1422 part 2, NAA, Canberra. 
would lead to Fraser appointing him as Secretary of the Department of Foreign Affairs in the following year and sending the incumbent, Alan Renouf, to head the embassy in Washington. ${ }^{33}$

\section{The appointment of Alan Renouf}

Alan Renouf, like Sir James Plimsoll, was appointed as Australia's Ambassador to the US after heading the Department of Foreign Affairs. Renouf's appointment in Washington began on 1 February 1977 and finished towards the end of 1979. Born in Sydney on 21 March 1919, Renouf was educated at Sydney High School and then the University of Sydney. After service in the Australian Imperial Force from 1939 to 1943, he joined the Department of External Affairs. His career included several postings in the US. He was Counsellor in the Australian Permanent Mission to the UN, New York, from 1946 to 1949; First Secretary in Washington from 1954 to 1956; and Minister, deputy head of mission, in the embassy in Washington from 1963 to 1965. Prior to his appointment as Ambassador to the US, he had been head of mission in Nigeria from 1961 to 1963 and in Paris from 1969 to 1973. After Waller stepped down as Secretary of the Department of Foreign Affairs in 1974, Whitlam appointed him as his replacement, a position he held until 1977.

Renouf's appointment to Washington came about through a falling out with Fraser that began in 1975 when Fraser was Leader of the Opposition and Renouf was still the Permanent Secretary of the Department of Foreign Affairs. As Renouf recalled it, he had been invited to speak to an audience of more than 600 people at a Legacy Luncheon in the Great Hall in Newcastle in the second half of 1975. Renouf's Newcastle speech angered Fraser when the latter received reports that Renouf had been excessively vigorous in defending the Labor Government's foreign policy against Opposition criticism. Fraser rang Renouf to allege that 'I hear from the press that you made a speech in Newcastle at mid-day today which was very much in favour of the government and you spoke very much like a Labor Party minister'. ${ }^{34}$

33 Fraser to Parkinson, n.d. (August 1976?), letter, series A1209, item 1976/1422, part 2, NAA, Canberra.

34 Alan Renouf, interview, 23 November 1993, transcript, NLA, 138. 
To Renouf's defence that he was only reciting government policy, Fraser retorted: 'Oh, you went much further than a public servant should go, according to what I hear.' ${ }^{35}$

After Fraser became Prime Minister in 1975, Renouf remained as head of the Department of Foreign Affairs, but the problems between the two men resurfaced when Fraser made a visit to the People's Republic of China in 1976 before making his first visit to the US. During this trip to China, Fraser floated the idea of a four-power military grouping between the US, Australia, the People's Republic of China and Japan. The Fraser Government was greatly embarrassed when a junior official in Australia's embassy in Beijing leaked copies of the top secret record of the meeting. Fraser placed the blame for the leak squarely on Renouf as Secretary of the Department of Foreign Affairs and, not long afterwards, he informed Renouf that he was removing him as Permanent Secretary. In an appointment with Fraser, Renouf remonstrated that 'as a permanent head I'm entitled to a position at the same level, and unless you offer me a position at the same level, which I'm prepared to accept, you can't get rid of me' ${ }^{36}$ Fraser then asked Renouf where he wanted to go to which Renouf replied that 'I'll only go to one place. I'll go to Washington'. ${ }^{37}$

Fraser agreed to Renouf's request and asked the Minister for Foreign Affairs, Andrew Peacock, to arrange it. As a consequence, the incumbent Ambassador to the US, Nicholas Parkinson, was brought back to Canberra and appointed Permanent Secretary of the Department of Foreign Affairs, while Renouf succeeded Parkinson in Washington. So incensed was Renouf about the manner of his removal as secretary that he declined the offer of a knighthood and also returned his Order of the British Empire. Renouf arrived in Washington in February 1977 and presented his credentials as Ambassador on 17 February. His connections in the US and understanding of the workings of the American political system gave him a strong advantage as immediately noted by Cyrus Vance, the US Secretary of State, who was able to comment that 'Australia had a great Ambassador here in Washington who had quickly established excellent contacts'. ${ }^{38}$ Although Renouf had

35 Ibid.

36 Ibid., 148.

37 Ibid., 149.

38 Record of the Minister's Conversation with Secretary of State, Cyrus Vance, 25 March 1977, series A1838, item 250/9/10/2 part 6, NAA, Canberra. 
a poor relationship with Fraser, his experience and contacts in the US made him an effective Ambassador in Washington during a time when Australia-US relations were not particularly close.

\section{The ambassadors and the Carter Administration}

By the time that Renouf commenced his appointment in Washington, the Democrat Jimmy Carter had commenced his single term as President from 1977 to 1981 and Renouf was immediately involved in facilitating visits to Washington by Fraser and Peacock and in seeking to ensure that the new administration took account of Australian views in making its foreign policy. Carter was a Southerner from Atlanta, Georgia. When Renouf saw his Secretary of State, Cyrus Vance, on 9 February 1977, he entreated the Carter Administration to consult with Australia, as an 'old and trusted ally'. ${ }^{39}$ Renouf noted that the degree of such consultation in the past had not been 'satisfactory to the Australian Government which was one of those which had suffered from Kissinger's secrecy in years gone by (e.g. during the Vietnam peace negotiations)'. ${ }^{40}$

Renouf's concerns about lack of US consultation with Australia were quickly validated. Carter caused disquiet in Canberra when only two months into his administration he revealed that he had proposed to the Soviet Union that the Indian Ocean be completely demilitarised. The announcement came as a complete surprise to the Australian Government and Peacock remonstrated to Vance that the lack of prior consultation had 'hurt the Government of Australia'. ${ }^{41}$ Carter also worried the Australian Government by promoting 'trilateralism', a term referring to a preference for concerting agreement between North America, Japan and Western Europe. The Fraser Government worried that such an emphasis would marginalise Australia and the ANZUS alliance.

39 Renouf to Department of Foreign Affairs, 9 February 1977, cablegram no. WH43999 series A1838, item 250/9/10/2 part 4, NAA, Canberra.

40 Ibid.

41 Record of the Minister's Conversation with Secretary of State, Cyrus Vance, 25 March 1977, series A1838, item 250/9/10/2 part 6, NAA, Canberra. 
Renouf and the embassy arranged a visit by Peacock to the US in the latter part of March 1977. They organised meetings with Vice President Walter Mondale, with Secretary of State Vance and senior officials of his department, with Zbigniew Brzezinski, Carter's adviser on National Security Affairs, and with Paul Warnke, Director of the Arms Control and Disarmament Agency. Peacock reported that in these first extensive talks at the ministerial level with the Carter Administration, he had secured a positive response from Vance. ${ }^{42}$ The Secretary of State indicated to Peacock that while the Carter Administration viewed Australia primarily in terms of its important responsibilities in the South West Pacific Area, it would be seeking Australian advice 'across the board' on Southeast Asia and the Pacific. ${ }^{43}$ Peacock also took the advice of Renouf and his staff in Washington that there were limits to the degree to which the US would consult Australia. Peacock noted in a submission to Cabinet on 13 May 1977 the 'asymmetric' nature of the relationship, the fragmented nature of the policymaking process in the US, and Carter's penchant for 'thinking out loud' as reflected by his comments on demilitarisation of the Indian Ocean. ${ }^{44}$

Renouf then arranged a visit for Fraser with Carter in June 1977. This proved a more difficult task. In February, Renouf reported from Washington that considerable difficulties were being encountered in making firm arrangements for high-level visits to Washington to meet Carter. ${ }^{45}$ Renouf had to deploy all his skills to persuade the State Department to press Carter to agree to an official visit by Fraser. ${ }^{46}$ Finally, on 11 March 1977, Renouf went to Vance, telling him that Fraser led a Coalition Government that had 'constantly stuck with the United States through thick and thin' and that, on coming to power, his government had 'immediately set out to repair and repaired the damage done to that relationship by the previous Labor Government'. ${ }^{47}$ Vance's response was 'terse' and Renouf sensed that the 'Americans are becoming a little resentful of the pressure being applied on them'. ${ }^{48}$

42 Peacock to Cabinet, 13 May 1977, submission, series A1209, item 1244, NAA, Canberra.

43 Note of Minister's visit to the United States, c. March 1977, series A1838, item 250/9/10/2 part 5, NAA, Canberra.

44 Peacock to Cabinet, 13 May 1977, submission, series A1209, item 1244, NAA, Canberra.

45 Henderson to Peacock, 9 February 1977, cablegram no. CH471698, series A1209, NAA, Canberra.

46 Renouf to the Department of Foreign Affairs, 9 March 1977, cablegram no. WH45450, series A1209, NAA, Canberra.

47 Ibid.; Renouf to the Department of Foreign Affairs, 11 March 1977, cablegram no. WH25632, series A1209, item 1977/33 part 1, NAA, Canberra.

48 Ibid. 
Eventually, however, Renouf's diplomacy paid off when the White House agreed to an official visit by Fraser. An exasperated Renouf remarked that the episode brought out vividly that the:

long-standing tendency in Washington to take Australia for granted persists and perhaps has even become stronger now that Atlanta has 'occupied' Washington, with the partial eclipse of the W.A.S.P. and Yankee establishment and with the prevailing input from what is left of the establishment being 'trilateral'. ${ }^{49}$

Renouf drew the lesson: '[i]t is only from being tough, when necessary, and even nasty, when necessary, can we hope to have proper influence in Washington'. ${ }^{50}$

Despite the difficulties in organising it, the prime ministerial visit was a success. Carter welcomed Fraser in an elaborate ceremony on the South Lawn of the White House. He spoke warmly of the many values shared with Australia and Fraser reciprocated the common concern of the two countries over the inability of many countries to escape from poverty, growing concern over the availability of energy resources, and the denial of fundamental freedoms to many people in many countries'. ${ }^{51}$ Carter added that Australia was 'setting an example for us and other nations to emulate. And our nation's commitments to non-proliferation will certainly be strengthened and enhanced by the fine example that has been set by Prime Minister Fraser and his own government in Australia'. ${ }^{52}$

Carter was referring with approval to the decision of the Fraser Government to export Australian supplies of uranium to other countries subject to safeguards. The US applauded this decision because Carter's nonproliferation policy was aimed at preventing a plutonium-based energy economy and discouraging fast-breeder nuclear reactors, the likeliest source of weapons-grade fissile material. ${ }^{53}$ Avoiding such a plutonium-based energy economy meant supplying enough uranium to countries to avoid their having to reprocess the mineral and thus produce a much more dangerous form of plutonium that might produce

49 Renouf to Parkinson, 21 March 1977, cablegram no. WH46070, series A1209, item 1977/33 part 1 , NAA, Canberra.

50 Ibid.

51 Barclay, 'Australia and North America', p. 148.

52 Ibid.

53 Coral Bell, Dependent Ally: A Study in Australian Foreign Policy, Oxford University Press, Melbourne, 1988, p. 152. 
sufficient fissionable material for a military device. ${ }^{54}$ Australia was important here because of its world-class deposits of uranium, many of which had been discovered in the late 1960s and early 1970s. ${ }^{55}$ Fraser thanked Renouf for organising the visit but reserved his most effusive gratitude for Denis Argall, counsellor in the embassy, whom he asked to pass on to colleagues in the embassy the gratitude of all the delegation that visited the US. ${ }^{56}$

While Australia's decision to export uranium was a positive for the Australia-US relationship, in important respects Australia-US relations drifted during Renouf's term as head of mission in Washington from 1977 to 1979. Indeed, the Fraser Government became concerned that the security relationship between Australia and the US was 'withering on the vine' as it became apparent that the US was winding down its military commitments in the Pacific and Indian Oceans. ${ }^{57}$ The academic FA Mediansky had highlighted this drift in May 1976 when he commented:

The diminishing role of the ANZUS alliance in United States eyes is related to America's reduced military power and interests in South East Asia. The defence relationship was more important in the 1960s when the United States was the most powerful military nation in South East Asia. By contrast the last four years have seen the run-down of its military capability in Indo-China and Thailand with possible reductions in the Philippines to follow. The awesome encirclement of China is now a thing of the past. ${ }^{58}$

The US had withdrawn its forces from Thailand and Taiwan and was planning to leave the Korean Peninsula by 1984. What made these developments of greater concern to Australia was that the Soviet Union at the same time had deployed twice the naval tonnages and five times the number of aircraft in the region. A July 1977 brief from the Australian Department of Foreign Affairs made the observation that the 'confidence of Australia's regional associates in continued US

54 'Mondale likely to discuss nuclear treaty', Sydney Morning Herald, 21 February 1978.

55 Carter to Fraser, 29 June 1977, letter, series A1209, item 1977/33 part 1, NAA, Canberra.

56 Fraser to Argall, 11 July 1977, letter, series A1209, item 1977/33 part 1 NAA, Canberra.

57 Barclay, 'Australia and North America', p. 149.

58 Fedor Alexander Mediansky, 'The diminishing role of ANZUS', Sydney Morning Herald, 4 May 1976. 
support was thoroughly shaken by Vietnam and has not yet been fully recovered'. ${ }^{59}$ Carter's 1977 announcement of plans to demilitarise the Indian Ocean only exacerbated Australian anxieties.

Consequently, the Fraser Government waged a political campaign that lasted more than a year after Carter's Indian Ocean announcement to secure a tacit or de facto interpretation of the ANZUS Treaty to make it clear to other parties that the pact concerned the Indian Ocean as well as the Pacific Ocean. The text of the ANZUS Treaty referred specifically to Pacific territories, but it also spoke of the 'metropolitan territory of the powers' that in Australia's case included the section of its coastline that faced the Indian Ocean. ${ }^{60}$ During the last year of the Ford Administration, Fraser had succeeded in having the ANZUS Council give its 'informal approval' to Australia and the US developing defence cooperation in the Indian Ocean. ${ }^{61}$ The communique after the 1977 ANZUS Council specified that any arms limitation agreement in the Indian Ocean must be 'consistent with the security interests of the ANZUS parties. ${ }^{62}$

Renouf worked hard to achieve the Australian Government's objective. He helped persuade Vance to provide a letter assuring the ANZUS partners that if the US secured an agreement on the Indian Ocean with the Soviet Union, it would not in any way qualify or derogate from the US commitment to Australia or limit [US] freedom to act in implementing our commitment under the ANZUS Treaty'. ${ }^{63}$ Then, during the meeting of the ANZUS Council in Washington in June 1978, Renouf had the wording of the communique amended to read that any agreement between the US and the Soviet Union on the Indian Ocean 'must' not - rather than 'would' not - detract from the ANZUS alliance. ${ }^{64}$

Renouf ended his term as Ambassador to the US in July 1979. Some years after his retirement from the public service he made one more intervention relating to his time in Washington. This was to remedy

59 Strategic and International Policy Division, Department of Foreign Affairs, 'United States: Strategic Policies and Perceptions', series A1838, item 686/2/19 part 1, NAA, Canberra.

60 Bell, Dependent Ally, p. 149.

61 Frank Cranston, 'ANZUS Role Approved', Canberra Times, 8 August 1976.

62 Bell, Dependent Ally, p. 150.

63 Sydney Morning Herald, 10 June 1978; brief for Visit of Vice President Mondale 10-11 April 1978, series A1838, item 250/9/30 part 1, NAA, Canberra.

64 Renouf to the Department of Foreign Affairs, 6 June 1978, cablegram no. WH67624, series A1838, item 250/11/18 part 2, NAA, Canberra. 
the situation that prevailed when he was Ambassador and when the Australian Government was regarded as such a bad payer of hotel bills in the US that hotels across the country had refused credit to Australian representatives travelling on official business. Renouf told an Australian parliamentary inquiry in June 1982 that, during his term as Australian Ambassador to the US, he was distressed by delays in the payment of bills..$^{65}$ He pleaded:

I really believe the Australian Department of Finance should be told in Canberra to stop trying to save money by not paying bills on time ... We achieved the reputation in the United States that we were a bad credit risk. ${ }^{66}$

\section{Nicholas Parkinson (second term)}

Renouf returned from Washington in July 1979 and retired from the public service in August of that year. By that time Parkinson had been suffering from an affliction in his eyesight that made it hard for him to continue his duties as Secretary of the Department of Foreign Affairs. Consequently, Peter Henderson, a Deputy Secretary in the Department of Foreign Affairs, was appointed to succeed Parkinson as Secretary, while Parkinson presented his credentials as Ambassador to the US for the second time on 28 November 1979. In his welcoming remarks, Carter noted that 'an old friend has returned to us after a brief absence, and we are pleased to see that friend again'. ${ }^{67}$

Vietnam's invasion of Kampuchea in 1978 and China's subsequent incursion into Vietnam helped to revive US interest in Southeast Asia. This focus was extended to Southwest Asia and the Indian Ocean on 12 December 1979, a month after Parkinson arrived in Washington, when a Russian regiment seized the airport near Kabul, beginning 10 years of Soviet military intervention in Afghanistan. The Americans feared that extension of this intervention from Afghanistan to neighbouring Pakistan would bring the Russians to the shores of the Arabian Sea and in a position to threaten oil routes from the Middle East to the West. In support of the US efforts to restrain Soviet Union

65 'Australia—the bad payer', Sydney Morning Herald, 3 June 1982.

66 Ibid.

67 Embassy in Washington to Department of Foreign Affairs, 28 November 1979, cablegram no. WH84240, series A1838, item 1500/2/27/12 part 1, NAA, Canberra. 
expansion, the Fraser Government attempted to persuade members of the Australian team to boycott the Olympic Games in Moscow. In addition, Fraser announced that he had '[i]mmediately made an offer to the United States to consult with them concerning greater Australian involvement in patrolling and surveillance of the Indian Ocean' ${ }^{68}$

In the aftermath of the Soviet intervention in Afghanistan, Australia's stocks with the Carter Administration rose high. Parkinson organised another prime ministerial visit to Washington from 30 January to 1 February 1980 at which Fraser and Carter discussed the situation in Afghanistan and the revolutionary situation in Iran where officers of the US embassy in Tehran had been taken hostage. During that visit, Fraser declared that the Russian invasion of Afghanistan had established a 'more dangerous situation than that which prevailed in Berlin, or Cuba, or Korea in earlier times'. ${ }^{69}$ Carter shared this assessment. In his State of the Union Address on 23 January 1980, the President declared that an attempt to gain control of the Persian Gulf region would be repelled by all necessary means 'including military force'. ${ }^{70}$ The ANZUS Council meeting in Washington on 26 and 27 February 1980 noted that Australia would deploy a carrier taskforce in the Indian Ocean and that consultations at operational and policy levels 'take on a new urgency in the uncertain strategic prospects resulting from the present SouthWest Asia crisis, that operational planning in response to the crisis is well under way, and that additional measures are being explored'. ${ }^{71}$ For historian Glen Barclay, "[b]arely a year after reaching its nadir of irrelevancy, ANZUS was at last looking and sounding like a vehicle for genuine military cooperation that Australia had always wanted it to be'. ${ }^{72}$ In the beginning of the 1980s the Fraser Government further strengthened military cooperation by permitting US aircraft based at Guam to conduct training flights over Northern Queensland and to stage through Darwin on training and surveillance flights into the Indian Ocean.

68 Barclay, 'Australia and North America', p. 153.

69 Embassy in Washington to Department of Foreign Affairs, 31 January 1980, transcript of the Prime Minister's Press Conference, cablegram no. WH86510, series A1209, item 1980/64 part 1, NAA, Canberra.

70 Barclay, 'Australia and North America', p. 153.

71 Ibid., pp. 154-5.

72 Ibid., p. 155. 
Parkinson ended his second term as Ambassador to the US prematurely at the end of 1981 because of the persistence of the problem with his eyesight. ${ }^{73}$ On his return to Canberra, in an informal briefing to a subcommittee of the Joint Committee of Foreign Affairs and Defence on 25 February 1982, Parkinson emphasised that Australia in 1982 was regarded more seriously than ever before by what he called the US 'establishment' (that is, by the US Administration and Congress). He argued that the 'establishment' in the US had become 'more conscious of the strategic importance of Australia in a changing world situation and of the potential of Australia's resources'. ${ }^{74}$ On the other hand, Parkinson referred to the problem of what he labelled Australia's 'vanishing constituency' in the US. By this he meant the gradual disappearance from public life of the wartime generation that had forged that ANZUS alliance - including the likes of Eisenhower, John F Kennedy, John Foster Dulles, Dean Acheson and Dean Rusk. For this reason Parkinson thought that there was more reason for Australian diplomats to try to reach the 'voter' level, the ordinary public, more effectively. Far more than the letter of the ANZUS Treaty for Parkinson was that the American public should be aware of Australia. In the 1980s the challenge of extending Australian influence to Congress and the broader American public would become an increasing focus of the ambassador and the embassy in Washington.

\section{Conclusion}

The time 1972 and 1973 was a period of great instability in the Australia-US relationship and a major challenge for Sir James Plimsoll. Succeeding Plimsoll after 1973 were three career diplomats who worked hard to repair Australia-US relations. By the beginning of 1975, Sir Patrick Shaw had helped the Whitlam Government achieve what he described as a more independent relationship between Australia and the US. Shaw also navigated a period of political instability in two countries - the Watergate Crisis in Washington in 1974 and the dismissal of the Whitlam Government in 1975.

73 Parkinson to Henderson, 1 September 1981, letter, series A10476, TC-NFP part 2, NAA, Canberra.

74 Sir Nicholas Parkinson, former Australian Ambassador in Washington, to Joint Committee on Foreign Affairs and Defence, 28 February 1982, informal briefing, series A1838, item 250/9/1/7 part 1, NAA, Canberra. 
Shaw died in December 1975 before introducing a new Australian Coalition Government to Washington. This task fell to another experienced diplomat, Sir Nicholas Parkinson, who organised a successful visit by Fraser to Washington in 1976 before returning to Canberra to take up the position of Permanent Secretary of the Department of Foreign Affairs. Parkinson's successor, Alan Renouf, had perhaps the best preparation of any head of mission in Washington to that time, having served in the embassy twice before, once as deputy head of mission. He arrived in Washington in 1977, embittered by his removal as Secretary of the Department of Foreign Affairs. Nonetheless, he worked effectively to influence the Carter Administration and to combat what one interpreter described as the 'withering on the vine' of the security relationship. Renouf helped the Fraser Government achieve the tacit interpretation of the ANZUS Treaty to cover the Indian as well as the Pacific Ocean. He was succeeded at the end of 1979 by Parkinson again. In his second term, Parkinson presided over a security relationship that was much closer than the relationship of the mid-1970s because of developments in Southeast Asia and Southwest Asia. For Parkinson, however, one of the major challenges ahead in the 1980s was for the embassy in Washington to extend its influence in the US beyond the executive government.

The three ambassadors confronted different problems. Shaw had to deal with a relationship that had been fractured by ideologically opposed governments in the early 1970s. Hampered by a prime minister who distrusted him because of his supposed political affiliations, Renouf had to work especially hard to register Australian interests with the Carter Administration, which seemed to have downgraded Australia's political and strategic importance. Parkinson, struggling with the physical disability of his failing eyesight, identified Australia's 'vanishing constituency' in the US as a longer-term problem for all Australian governments. All three envoys were effective in different ways. Parkinson was an exemplary organiser, Renouf an assiduous networker and Shaw the persuasive advocate of a reforming government. 
This text is taken from Australia goes to Washington: 75 years of Australian representation in the United States, edited by David Lowe, David Lee and Carl Bridge, published 2016 by ANU Press, The Australian National University, Canberra, Australia. 